\title{
Could /can we prevent mental and physical injuries at work by acting on managers?
}

\section{¿Podemos prevenir las lesiones mentales y físicas en el trabajo actuando sobre los directivos?}

DOI: $10.46981 /$ sfjhv2n4-001

Received in: Oct 1st, 2021

Accepted in: Dec 31th, 2021

\author{
Eliane Garnier-Daujard \\ French-Luxembourgish doctor of ergonomics and psychologist. \\ Institution: CENOLIA PORTAGE \\ Address: 7, avenue Beregovoy 18000 Bourges, France. \\ Email: el.garnier@wanadoo.fr
}

\begin{abstract}
Nowadays, in a waving working world managers could and can play an important role in the process enable people to find wellbeing at workplace and some people believe they can no more work as correctly and efficiently than before. Often, as a psychologist I hear difficulties encountered by people who are suffering in an occupational world where they sometimes become mentally and physically injured. Many of their problems seem to be induced by their occupational environment, more specifically by management practices. The aim of this paper is on one hand to identify and explain some inappropriate management practices which are often applied by managers, and then on another hand to underline effects of those management practices on wellbeing at work, essentially not only as a function of the difficulties or problems encountered by workers but also in relationship with potential psycho(sociological) effects of some management practices on the workers. Even if the key points and proposals mentioned in that article must be considered to be a suggested framework to be brought to the attention of managers, we firmly believe that the transformation of management practices from an instrument of suffering into an instrument of wellbeing can /could happen, in particular through a caseby-case training of managers / leaders.
\end{abstract}

Keywords: burn out, defense mechanisms, double bind patterns, guilt, leader, management, manager, mental health, neurosis (war neurosis, i.e. kriegsneurose; traumatic neurosis), ptsd, qwl, reification, rsi, stress, training, wellbeing \& suffering at work.

\section{RESUMEN}

Hoy en día, en un mundo laboral tan cambiante, los directivos pueden desempeñar un papel importante en el proceso que permite a las personas encontrar el bienestar en el lugar de trabajo y algunas personas creen que ya no pueden trabajar tan correcta y eficazmente como antes. A menudo, como psicóloga, escucho las dificultades que encuentran las personas que sufren en un mundo laboral en el que a veces se lesionan mental y físicamente. Muchos de sus problemas parecen estar inducidos por su entorno laboral, más concretamente por las prácticas de gestión. El objetivo de este trabajo es, por un lado, identificar y explicar algunas prácticas de gestión inadecuadas que suelen aplicar los directivos y, por otro, subrayar los efectos de esas prácticas de gestión sobre el bienestar en el trabajo, esencialmente no sólo en función de las dificultades o problemas que encuentran los trabajadores, sino también en relación con los posibles efectos psico(sociológicos) de algunas prácticas de gestión sobre los trabajadores. Aunque los puntos clave y las propuestas mencionadas en ese artículo deben considerarse como un marco sugerido para llamar la atención de los directivos, creemos firmemente que la transformación de 
las prácticas de gestión de un instrumento de sufrimiento en un instrumento de bienestar puede/podría ocurrir, en particular a través de una formación caso por caso de los directivos/líderes.

Palabras clave: burn out, mecanismos de defensa, patrones de doble vínculo, culpa, líder, gestión, gerente, salud mental, neurosis (neurosis de guerra, es decir, kriegsneurose; neurosis traumática), tept, qwl, reificación, rsi, estrés, formación, bienestar y sufrimiento en el trabajo.

\section{INTRODUCCIÓN}

This article is an extension of a short PowerPoint presented in 2019 in the $5^{\text {th }}$ International Conference on Wellbeing at Work in Issy-les-Moulineaux (France). The data as reports from the field are extracted from results obtained on more than 5,000 diverse and various people met over more than 20 years, whether as patients received face-to-face or as workers investigated in surveys / valuations about prevention of occupational health diseases. As a psychologist, we often receive people, whether employees, handworkers or managers, who suffer at work, and sometimes since a long time. Nowadays, it seems to us that the relationship between the so-called "toxic management" (M. Thevenet, 2008) practices and occupational diseases is more specifically and very often concerned. Diverse effects of management practices are pathogenic and could affect working conditions, and thus wellbeing at work. Our proposals for improving the QWT (Quality of Work Life) must be considered to be a suggested framework to be used by managers as means and tools for developing their skills to allow their subordinates to avoid suffering at work on the basis of a diagnosis related to (socio)psychological concepts.

\section{METHOD}

The main characteristics of the method are described below. It integrates the occupational environment and its evolution within the 3 last decades. In Europe, especially in France, both following aspects seem to represent the background of the current framework: the European directive 89/391/EEC published on 06/12/1989; new words and expressions successively introduced in the occupational world. Among the concepts gradually appearing over the 30 last years, we can mention those relating to the physical and mental health (e.g. and respectively: Repetitive Strain Injuries / RSI. and Post-Traumatic Stress Disorder / PTSD) and another very often used by managers (QWL, wellbeing and pleasure at work, suicide prevention, etc.). Among the problems encountered at the workplace we have often discovered links between suffering at work in its wide sense and management practices. Therefore, the managers have a major role to play in the process allowing working people to reach wellbeing and to prevent suffering at work. 


\section{OUR INVESTIGATIONS}

The below-mentioned data have been collected on one side in several surveys, the most of them having been carried out in France and a few of them in Europe, and on another side from patients received face-to-face in France $(\simeq 10 \%$ were bi-national). Audits, surveys or collective management trainings have been carried out in many organizations belonging to a wide range of sectors (trading, transport, agriculture, industrial and administrative sectors, etc.). The studies have been carried out on the request of a Director, a Head Manager, Social Partners, or legal institutions, etc. Most people received face-to-face in the last ten years in France mainly belonged either to small organizations or to the public sector like hospitals, local collectivities, education, etc. Data were collected in different ways. We have used adequate questionnaires related to the aim of our study: the items investigated have been elaborated by ourself or in collaboration with occupational doctors, employees, workers, social partners, employers, etc. Sometimes, we have proposed to extend or modify an investigation tool existing in the organization (either having been designed by the organization or belonging to a well-known investigation method like Karasek's / Siegrist's questionnaire). In order to collect as much practical and factual data as possible, as much open questions as necessary to meet that aim have been included. However, three kinds of inquiry have been used: data were collected by computer surveys or during face-to-face interviews / consultations or at workstation or during trainings, whether for managers or subordinates. Concerning the sampling and the sample, we are aware of the fact that only the data related to the purpose of this present study have been chosen because, in our opinion, it was the best way of collecting random data illustrating the relationship between some management practices and occupational health.

Overview on investigated people. Over the last twenty years we collected data concerning people whose main characteristics are listed in the tables 1 and 2 below. The data shown refer to the number of workers having been met, to the kind of work carried out (handwork or administrative work), and to the size of the organization to which they belong (less than 100; between 100 and 1,000; more than 1,000 employees). As concerns the distinction between men and women, we consider it of minor importance related to the number of people which could be investigated. With regards to the number of organizations and years where data have been collected and to the number of possible working people which could have been investigated, it seemed to be hard to select a sample being representative of the whole working population. 
Table 1. Summarized data about audits, surveys, or trainings carried out in organizations.

\begin{tabular}{|c|c|c|c|}
\hline & \multicolumn{3}{|c|}{ Size of the organization } \\
\hline Kind of work & $<100$ workers & $\geq 100 \& \leq 1,000$ workers & $>1,000$ workers \\
\hline Administrative work & 1,000 & 2,000 & 5,000 \\
\hline Handwork & 200 & 4,000 & 2,000 \\
\hline
\end{tabular}

In the table 1 above we can see people investigated in small and big organizations are more administrative employees than handworkers (1,000 vs. 200 and 5,000 vs. 2,000). As concerns people working in medium-sized organizations (between 100 and 1,000 employees), the ratio is inverted (2,000 vs. 4,000). We can note that the $\%$ of handworkers investigated in big organizations is smaller than the $\%$ of administrative people. We will add the data taken in account in the table 1 only concern the employees having fulfilled a questionnaire received by email: $\simeq$ between 30 and $50 \%$ of the total recipients fulfilled that questionnaire.

Table 2. Summarized data concerning patients received face-to-face in the last ten years.

\begin{tabular}{|c|c|c|c|}
\hline & \multicolumn{3}{|c|}{ Size of the organization } \\
\hline Kind of work & $<100$ workers & $\geq 100 \& \leq 1,000$ workers & $>1,000$ workers \\
\hline Administrative work & 88 & 95 & 10 \\
\hline Handwork & 0 & 8 & 0 \\
\hline
\end{tabular}

As concerns the patients received face-to-face in the last ten years, many of them are administrative people working in small and medium-sized organizations. In the table 2 above look at the very low number of handworkers who have decided themselves to consult a psychologist. If we compare the data shown in the table 1 with those mentioned in the table 2, how can we explain the very low rate of handworkers who consult a psychologist? Perhaps they decide to consult after having met a doctor or talked with friends, parents or coworkers. However, French people seldom consult at their own initiative. We will add that almost all handworkers shown in the table 2 worked or had worked in public hospitals or local collectivities in France. Concerning administrative workers, $60 \%$ of them are females (50\% of them were home-care aides, nurses and worked in small organizations, $20 \%$ were teachers in public or private sector, and $20 \%$ managers).

Data processing. 30 years ago, we published a first basic model (Daujard, 1986), which has been largely improved and up-to-dated over the years [Figure 1 shown below, Daujard, 1986]: it allows us to take in account all the necessary and sufficient elements, parameters and factors which could be involved in suffering-at-work, whatever the occupational conditions and contingences. That background model consists of 3 "sets" (human being, human environment, physical environment) which are intertwined and constantly interact with one another as a function of time and space. That model must be used as a tool for investigating, identifying, and analyzing critical pathogenic factors and parameters, and then for elaborating proposals to improve working conditions; however, those proposals must be designed in 
collaboration, partnership and coworking with people directly or indirectly affected, whether managers or subordinates. The managers can also 'deal' with those sets in a constantly waving working world to help workers to perform their tasks as efficiently and stress-free as possible, and to increase and enhance their competencies, skills and abilities.

Figure 1. Improved and up-to-dated background model, designed in order to prevent, amongst other things, diseases and disorders at work.

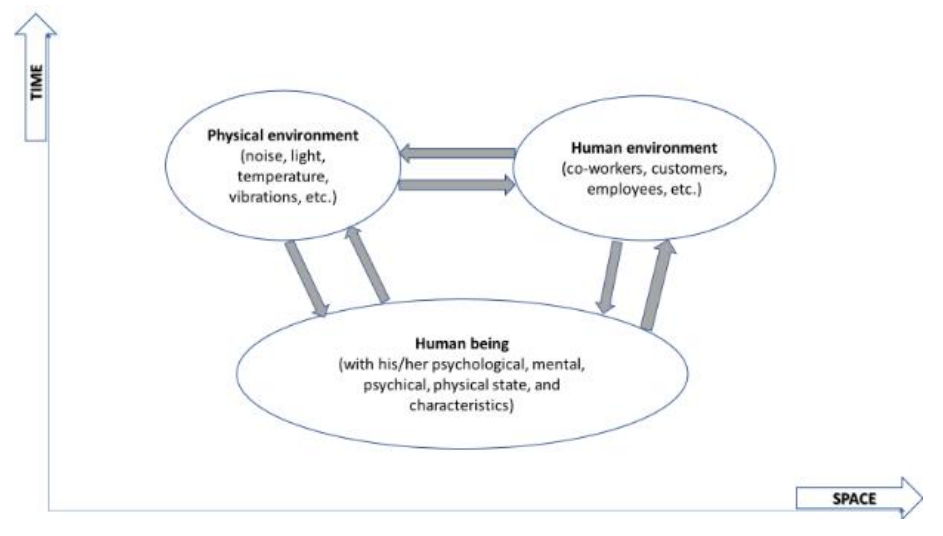

\section{RESULTS}

relationships between management practices and suffering at work. Managers could / can play a very important role in the process allowing workers to avoid stress and other pathogenic feelings. Often, amongst the diverse origins of occupational diseases, we have identified some management practices which could induce iatrogenic and pathogenic effects on workers (in that article the word "worker" means, unless otherwise specified, employee, handworker, workman, manager, or leader, etc., that is to say all people who belong to the working population). In order to discover intertwined links between management principles and wellbeing at work, we have investigated and analyzed relationships between suffering at work and management practices, which should be seen in the light of the potentially pathogenic items involved into those practices; after that, we have analyzed and studied the possible pathogenic factors and their effects as a function of concepts related to psychology and sociology of organizations. The results of our study are reported below. 7 key points belonging to a non-exhaustive blacklist of management practices have been selected.

\section{FIRST KEY POINT}

neither method nor principle of management is used. 'Management' and 'manager' are both polysemous words; it is perhaps for that reason that some people sometimes believe that not only everybody can manage but also that management is very easy to perform. Unfortunately, that is not the case. In fact, it happens that some leaders manage without applying any management principle; they are 
leading their subordinates haphazardly, sometimes are 'surfing in the prevailing wind direction', but often are 'lost in the storm'. Why do they do that? In order to answer, we will mention two possible main causes: firstly, their lack of knowledge, experience, and expertise in conjunction with an iterative lack of time; secondly, the so-called "casting errors". The next example illustrates a "casting error" encountered by investigating in a shipping hub where approximately 50 people worked on an area of o10,763.9 $\mathrm{ft}^{2}$. In that hub, at midnight, we observed a manager coming from a team to which he had belonged as a subordinate; that inexperienced manager sometimes did nothing, but sometimes, did tasks to be carried out by his subordinates and often yelled: "You don't know how to work." Subordinates became stressed because nobody knew what to do or to say; their ability to work was restricted, impeded or hindered because they always work under pressure. In fact, the manager drove a self-propelled industrial truck at a very high speed, made shipping errors, carried a load exceeding the allowed weight from a place to another at the highest speed, and thus without looking at anything or anybody around. His subordinates were afraid of such occupational surroundings and often preferred to 'wait and see'. Indeed, serious consequences were induced and the subordinates were stressed, though the manager firmly believed he was doing the right thing, and thus because he was not aware of his errors. Therefore, to improve his management abilities, competences and skills, we have built an individually targeted training and designed a personal customized coaching in order to prevent negative psychological effects on that manager and his subordinates. He was trained and coached as follows: after having observed and analyzed, under real working conditions, the shipping tasks to be done by his subordinates, that manager was going to try to understand the causes of his main errors. Nowadays, he is able to manage his subordinates without inducing stress on them and he tries to avoid potential errors.

\section{SECOND KEY POINT}

stress-based management. As a representative example of 'toxic management' we will mention the behavior of some future managers. As a teacher in a French engineer school, we asked students about their proposals for making a brief speech about a management matter and some of them answered: "About stress-based management". We refused to validate that theme of speech and those future managers were disappointed. "Why could we not manage by inducing stress upon our subordinates because we can talk about good stress?" Our answer was the following: "Even if some people say stressful constraints are good because of good stress, we cannot agree with such a view". In fact, when people are talking about good stress, they very often think as said Taylor: the handworkers received " 60 . per cent. more wages than other workmen around them " (Taylor, 1911); however, those workers became physically and mentally overloaded because the increase in wages couldn't offset a constant physical and psychical overworking. If such a 'good stress' is induced, the other side of the coin is that workmen 
are not able to bear such an overloading, whether physically or mentally, during a long time because they are not robots. Even if handworkers always go faster and faster to do more and more tasks within the same amount of time, what kind of benefits will they get? Firstly, higher wages, but secondly, very high overload and often occupational diseases and health injuries. Indeed, even if the marathon runner thinks he has to go faster and faster to win a race or a sporting event, the difference between a runner and a worker could be summarized as follows: although some professional runners exist, we cannot compare a pleasure (for instance running) and a means allowing people to live and survive. Moreover, the etiology of the so-called 'good stress' appears to be similar to that of a drug addiction which could induce major depressive disorders, depression, etc., which sometimes conduct workers to death from suicide or karoshi (that Japanese word 'karoshi' means "overwork death"). Sometimes, we have met managers who were applying the so-called stress-based management "method". Why? The main causes seemed to be the fear of job loss and a blind obedience to the highest authority (Arendt, $1951 \& 1977$; Bourricaud, 1961; Milgram, 1974; Lunt, 2009) because managers preferred to obey to the hierarchy's orders without thinking than to get problems which could hinder their career; when stressful constraints are applied to the managers by the upper hierarchy level it often happens that they firmly believe that the constraints (deadlines, time, high and strong productivity requirements) applied on them by the head of the organization have to be applied on their subordinates (Miller, 1980). Nevertheless, it happens that managers did not quite agree with a stress-based management but they firmly believe "the end justifies the means". However, that kind of management can induce, even out of the worktime, violence, diseases, strained relationships between managers and their subordinates, and several iatrogenic effects already mentioned above in that paper. When we encounter a case of stress-based management, we always try to talk about it with the manager, and sometimes if necessary, with the upper hierarchy level whose answer is often the following: "We can't do anything without closing the factory".

The next example illustrates such a practice and its pathogenic effects. In a French factory $(2,000$ people) located in an area where the job offer was very limited, we had filmed 25 people working on an assembly line in order to prove that the major cause of stress was recurrent part supply disruptions, very iterative breakdowns on the line, high decreases in productivity because many failures. In addition to repetitive breakdowns, the workers were overloaded, in particular by iterative orders given by the manager and rendered inaudible to the handworkers because of the ambient noise surrounding the workers who, in addition, knew that the daily production rate would not be performed and that they would work on Saturdays, as expressly required by their contractual agreement. So, they were unable to foresee any private event with their family because the fear of losing their job had conducted them to sign a working-time flexibility contract. After having watched the one hour-long film illustrating workers' activity and heard our explanations concerning the possible causes and potential effects on the 
workers, the director said: "But the workers can rest when breakdowns occur!" Though we had explained with statistical and factual data that recurrent breakdowns were not similar to recovery breaks and are not only one cause of the increase in stress but also the main cause of the decrease in efficiency and productivity, that director didn't “understand” our explanations. However, it seems reasonable to think that his opinion was based to a Taylorian view, especially when Taylor said that the workmen always go slow and deliberately keep "their employers ignorant of how fast work can be done" (Taylor, 1911). On one side the previous example illustrates the difficulties encountered by the lower hierarchy level to report problems to a director. Indeed, since that director did not "understand", it seems to be clear that none of his subordinates could lead him to "understand" any explanation. It seems to use that managers often apply a "stress-based management method", whether consciously or not, or perhaps because of an ostrich-like policy, and thus without being aware of the consequences on workers' health.

The previous explanations confirm the major importance to sensitize the upper hierarchy level to management practices inducing diseases and injuries at workplace. However, the lack of 'understanding' associated with a lack of organization at the highest level of a factory might induce, amongst other effects, stress, burn-out, and brown-out (in particular when no sense, or more or less great meaning could be given by the workers to their tasks). Socio-economically speaking, we will add that, a few months after our study, the number of handworkers in that plant have begun to decrease and year after year more than half of handworkers had lost their job and every year more than one director left the organization.

Third key point: workers are interchangeable as a function of space and time. Amongst the factors involved in occupational diseases we will include the management 'method' based upon the interchangeability of workers, whose autonomy either no longer exists or is more or less reduced because of the effects of a 'toxic' management; in fact, workers can be displaced or interchanged at any time and without any explanation, in order to increase the efficiency of the production process. Indeed, a worker is neither a pawn on a chessboard nor a "thing", neither a number nor a registration number. Furthermore, in such surroundings the workers are considered like "res", in other word "things" in Latin. Psychologically speaking, we talk about "reification", i.e. "becoming a thing". Amongst the main effects of that reification we can mention the following ones: no sense can be given to the tasks to be carried out; the workers lose not only their physical references, especially in time and space but also their autonomy and identity at work. That loss of identity could result from iterative and stochastic changes in the content of the tasks. The French psychiatrist C. Dejours and J. P. Deranty, Professor in Department of philosophy in Australian Macquarie University, point out the "centrality of work" (Dejours \& Deranty, 2015) in the human life, whether mentally, psychologically, sociologically or financially. In fact, the work allows people to think, to develop new skills, abilities, and competences but, when workers are used as pawns, they are dehumanized, which is the case in some organizations 
too when all private things like family or children photos are forbidden, whether they lay on a desk or hang on a wall.

The following sentence could become a 'red wire' to be included in a training for managers: the worker has "to cease being a thing and to become a creator" (Fromm, 1967). To reach this aim, workers and their manager together could elaborate new kinds, ways and manners of working and then make proposals to be tested during and after an adequate training in order to improve their working conditions. Very often, we have managed such training sessions where workers and their manager were talking together about the tasks carried out or to be done, and then tried to discover and to propose new ideas to be tested on site; finally, if applicable and possible, these proposals could be validated by all working people, that is to say workers and their manager. Such a kind of training allows managers to better understand, and then, if possible, to be aware of that: it is dangerous to apply any management method haphazardly. Furthermore, a case-to-case training can incite and allow managers to prevent not only the reification of workers but also the occurrence of occupational diseases.

Fourth key point: “The right man"; the "one best way”. The well-known book 'The principles of scientific management' was written "to prove ... that the best management is a true science" and that "the fundamental principles of scientific management are applicable to all kinds of human activities" (Taylor, 1911). Concerning handworkers, we will summarize Taylor's opinion in both following mythic expressions: "The right man", whether handworker or employee, and "the one best way", that is to say the "tasks are carefully planned", including "the exact time allowed for doing" them. In our opinion, on one side Taylor's rules do not entirely take into account the skills, abilities, and competences of the workers though the "first step" of the recruiting process is "the scientific selection of the workman"; on the other side those principles could only take in account not only the opinion, viewpoint and belief of the head manager, i.e. very often the opinion of the engineer applying the 'fundamental principles of scientific management', but also the workman who is dehumanized, i.e. almost 'exempt from any mind or thought'. What did Taylor mean by "right" and "best"? "Right" and "best" from whose point of view? When he talked about a workman, he said: "He may be able to do, generally speaking, the highest grade of work for which his natural abilities fit him" (Taylor, 1911). Do the previously mentioned Taylor's sentences imply that the workers cannot change anything in their working manner and style because they couldn't improve their "natural abilities" (Taylor, 1911)? Can we think and say that a worker "is no longer recognized as homo faber but treat as an animal laborans" (Arendt, 1951) and, among other things, he becomes an "isolated man who lost his place in the political realm of action" (Arendt, 1951)? If we look at the set "human being" above illustrated [Figure 1, Daujard, 1986], we can understand why a worker must be seen as a whole human unit and entity and cannot be observed as a man cut into various pieces without links between one another. In fact, studying only "the highest grade of" (Taylor, 1911) 
physical "work" would be helpful but wholly insufficient because physical load and mental load are linked and intertwined; therefore, we have to investigate, study and analyze them in relationship with one another. If not, we will break up the worker into various and diverse parts. Such a situation can relatively often be observed, in particular when an organization runs both day and night and the handworkers are on a 3 -week rotation cycle (the $1^{\text {st }}$ week in the morning, the $2^{\text {nd }}$ week in the afternoon and the $3^{\text {rd }}$ at night). Nevertheless, we have to take into account both aspects: 1 . people working on an assembly line are very limited in the flexibility related to the tasks to be performed and we can consider that, in such a configuration, the iatrogenic effects on working people will be approximately similar to those mentioned in the $3^{\text {rd }}$ key point described above; 2. sometimes, people working at an "individual" workplace can search for, and then discover more possibilities to modify their manner of carrying out the tasks, and thus to reduce the health risks. These Taylor's principles / rules could mean that a workman is not a thinking being but a robot because he carries out tasks without thinking, though a handworker is both a human being and a thinking being. In our sense, the possible, useful, and helpful way to struggle against the risk of mental diseases under such working conditions would be an adequate training whose content must integrate the principles described under the $3^{\text {rd }}$ key point above. Indeed, at the end of a training session managers should be able to ask themselves about their practices and, in the most cases, to change their mind about their previous managerial behavior after having talked about and analyzed their practices, preferably with their peers, but sometimes also with their hierarchy and their subordinates. However, to partially exonerate the managers, we will also mention that they are not always aware of the potential pathogenic effects of their malevolent managerial behavior on the mental and psychical health of the workers. We will add it appears today that Taylor was not aware of the iatrogenic pathogenic effects of the "scientific management" on the handworkers when he wrote "In no case is the workman called upon to work at a pace which would be injurious to his health" (Taylor, 2011).

\section{FIFTH KEY POINT: NO COMMUNICATION OR LOW COMMUNICATION, OR COMMUNICATION FAILURE.}

More and more frequently, we encounter failures in communication because of recurrent time constraints, productivity requirements, lack of staff, increase in workload, etc. Thus, under those surroundings, the "manager is always right", many subordinates said. That kind of management through an on/off function can induce diseases at all levels of the organization because every pressure can be applied everywhere at every time, whether by managers on handworkers or on managers by their hierarchy. So, some managers often prefer to obey the orders than to disobey the instructions given by their hierarchy (Milgram, 1974). Therefore, it often happens that managers change their mind as a 
function of the orders received and the workers can no longer work as efficiently and correctly as possible when they often do not know what is expected from them. Amongst other negative effects we will mention mental, psychical, and physical overloading, which can conduct workers into violence and induce disobedience to authority, and even strike. That blind obedience to the highest authority could generate, among other things, failures and errors, and very often, neither the workers nor their manager can do anything against the causes and the pathogenic consequences of that lack of communication coming from the highest hierarchy levels.

However, communication is essential for human life; several negative effects can occur because of poor or low communication not only between upper and lower hierarchy levels, but also between subordinates. Unfortunately, the previous example (cf. the $2^{\text {nd }}$ key point above) illustrates difficulties in persuading the highest hierarchy level of the great importance of avoiding health diseases, which are also very often associated with high absenteeism.

The French psychiatrist and ergonomist R. Mucchielli (1976) had defined 3 variables integrated in the authority relationship between the subordinates and their manager (cf. explanations under the $6^{\text {th }}$ key point below): 1. Situation; 2. Group (a group is larger than a team); 3. Manager's personality. We always talk with managers about those 3 variables when we organize a training session about communication concerning the tasks to be done by the workers. Such a training may lead the managers to focus their attention on the tasks carried out by their subordinates but also on their subordinates themselves when all or some people encounter difficulties, in particular in carrying out hard, uneasy, complicated, new, or unusual tasks. And, as a result, an active collaboration within all the members of a team could go on when the training has ceased, especially if a close collaboration on the basis of concrete cases has been initiated during the training. The next example seems to be representative of 'mismanagement' without any communication or adequate communication. After having identified suffering at work in the invoicing service of a factory (400 employees) located in France and belonging to a multinational organization, the head manager asked us to help him to avoid suffering at work. 6 people ( 5 women and their manager) were concerned by our study. Let us mention the following data concerning the background and the framework of our investigation: within the last 5 years 5 directors left the factory; the manager of the invoicing service was retired since more than a year and nobody managed the service; 7 months ago, a woman, who was previously a secretary in another service, had become the manager of that service; a new director had joined the organization eight months ago. The 'new' manager of the invoicing service had "designed a software able to do invoices very easily", she said. Although she knew nothing about invoicing process, she had decided to "develop a software to improve the performances" of her service. Indeed, after having elaborated requirements to create a "very good software", she had met a software development engineer, who has designed a software 
corresponding to the specifications provided by that manager. Unfortunately, the data given him were neither available in sufficient quantities and quality nor suitable for the tasks really and daily carried out by the employees. So, what had to happen has indeed happened: when the software was used for the first time, nobody could no longer work correctly. In fact, “double binds” (Bateson, 1969; Watzlawick and coll., 1967) occurred because it was not possible for the workers to perform their tasks, essentially for the following reasons: some essential data and linkages between data were not stored in the software; previous computer transactions and many technical words had been changed into user-unfriendly transactions and meaningless words respectively and, in addition, some words and transactions made no sense for the workers. That manager "is always right and cannot recognize her errors", the employees said. Among the effects of which we could call a "casting error" in the selection of the manager by the previous director, we will mention the following ones: the workers no longer trusted their manager because her authority was no more legitimate; the workers refused to communicate any longer with her; more than 2 workers were sick all the time and it was difficult for their coworkers to work efficiently due to overloading and overworking; the customers constantly called the workers because they found billing errors and the subordinates refused to answer the customers. However, after having met that manager face-to-face and talked with her about the problems encountered by her subordinates, we firmly believe that she wasn't aware of her malevolent management practices because her personality, competences and skills did not match these ones required for managing an invoicing service, and perhaps any service; "double binds", also called "contradictory injunctions", were induced because of pathogenic communication described by G. Bateson (1969) when he was studying the schizophrenic communication related to the "pathology in relationship". When a "double bind" occurs, any sort of 'normal' communication between people can no longer exist. Let us summarize that pathogenic communication process as follows: "A primary negative injunction" is given by A, then "a secondary injunction conflicting with the first at a more abstract level, and like the first enforced by punishments or signals which threaten survival" is emitted by A, and, after that, A emits "a tertiary negative injunction prohibiting the victim from escaping from the field ... Finally, the complete set of ingredients is no longer necessary when the victim has learned to perceive his universe in double bind patterns" (G. Bateson and Coll., 1969). For example, in the invoicing service previously described the primary injunction was the following: "Today, you must make 100 invoices" ... but all the tasks required by the manager couldn't be performed because a lack of essential data in the software; after one hour a secondary order is given: "Why are you working so slow as a snail?" ... but that last injunction was conflicting with the first order because the required tasks couldn't be performed and the manager couldn't answer the questions concerning the failures; and then the third order is given: "Here, you don't make invoicing because you are not able to change your mind about the manner of making invoices, 
though you use a very good software". The subordinates knew that their manager had no idea about their tasks and was often changing her mind; so, in order to preserve their health, they had set up their own defensive strategy against iterative double-binds. However, even if that defensive strategy can function at the beginning, it finally cannot go on and on forever because health diseases (for instance from stress to burnout, bore-out, etc. until suicide) will soon occur. Amongst other possible consequences of failures in communication, we can also mention the reification of employees used as interchangeable pawns on the wishes of the manager, double bind patterns, decrease in motivation, and perhaps war neuroses, of what we are going to talk.

For the first time at the end of the $1^{\text {st }}$ World War, S. Freud \& coll. (1918) talked about "Kriegsneurosen" ("war neuroses”). A war neurosis, K. Abraham said, is a traumatic neurosis consisting of a "symptom complex" whose manifestations can be "tremor, restless, excitability, susceptibility, insomnia, anxiety, depressed mood and feeling of inadequacy” (Abraham, 1918). Freud said (1918): "The war neuroses are ... traumatic neuroses which have been made possible because of a conflict ... between the previous pacific ego" (which previously existed during peacetime at work) "and the new soldier's ego" (the current ego existing during wartime, i.e. now at work). In other words, the war neurosis leads the worker to ask himself as follows: "Am I guilty of a crime?” As an analogical example, we would mention the situation encountered by the employee K. in Kafka's novel (Kafka, 1995) 'der Prozess'. As concerns the war neuroses which sometimes occur at work, we will summarize one of its main manifestations as follows: a war neurosis does not induce a remembering of a past traumatic event, but a reliving of it; therefore, the patient suffering from a war neurosis suddenly and unexpectedly relives an event having arisen in the past and having been repressed in his or her unconscious. We described below an example of war neuroses related to a patient who was suffering, in particular because of failures in communication. It concerns a 56-year-old German woman who was born 8 years after the end of the second World War. She consulted us because she couldn't get a job. Why? When she was sitting faceto-face with a potential employer, she was "paralyzed" by an unspeakable fear and, at the same time, her German father who had died a few years earlier suddenly appeared before her eyes next to her previous manager. This patient suffered from a war neurosis because the shadow of events, by which she had been deeply traumatized, remained. Why? A war neurosis is induced by a mental connection suddenly occurring between a traumatic past event and another one which, at the same time, (re)appears in the present and leads people to relive, whether partially or wholly, the previous traumatic event. Amongst the "things" which could awake a war neurosis, we can mention the lack of communication, violence, conflicts of values, double binds, etc. Concerning that patient, the war neurosis had been induced not only due to the unknown past of her father (Was he or wasn't a Nazi?) but also because of her previous experience with a manager in an organization where she had worked during a long time. In 
addition, she did not understand why she couldn't forget the pathogenic past events, though her coworkers had lived similar very negative events and had forgotten that 'bad' past where all kinds of communication were forbidden. We will add that her father was "violent, though he was an active member of the Catholic Church ... but it's very contradictory because Catholic people must obey to other values than violence", she said (see the $7^{\text {th }}$ key point about ethics). That patient relived a past event (manager's violence and lack of communication) which was reliving at the same time as another traumatic event (father's violence and lack of communication). This unexpected splitting between past and present suddenly arises from the patient's unconscious: his / her perception-consciousness of time and space disappears like in a dream state, except it is not a dream but a nightmare which induces psychical diseases. However, the patient must be treated. In that case, after the patient had understood and then was aware of it- why his father was violent, in particular after having investigated his possible past (in particular prison in Russia during 6 years, and then fear that a new world war might reoccur, etc.), the patient got another job. For that case and for many cases in order to treat or prevent suffering at work, we have applied 2 main principles: on the one side the patients must discover themselves, of course with our aid, the possible causes of their problems, and on the other side, if we deem it necessary, we strongly recommend them to read books that may be helpful for them (of course needless to say, we only recommend books which we have already read). The example above mentioned concerning war neuroses and often encountered today in Germany (Senfft, 2008) illustrates many intertwined links between private and occupational life; a war neurosis digs out the unconscious and intergenerational ghosts of the past (Third 'Reich') to change them in pathogenic shadows, in particular when it happens that managers, sometimes without any conscious intention of doing harm, do not communicate, or use unsuitable or pathogenic management means and tools able to induce double binds (for instance violence, power, inadequate communication, etc.) and, in addition, it often occurs that the workers feel themselves guilty, firmly believe it and say: "If I feel myself guilty, perhaps I'm guilty" Since it is hard to think logically when we are focusing our attention on ourselves (for example on a feeling of guilt), burnout and depression could arise. However, if the patients decide to talk about their feeling of guilt with a psychologist it will be easier to treat (Diel, 2007) them than when guilt is repressed in the unconscious.

Sixth key point: a good manager must also be an "authoritarian" one. In the Oxford Advanced Learner's Dictionary of Current English (Hornby, 1974), the word "authority" means "power or right to give orders and make others obey" or "person with special knowledge". What must be understood by manager's authority? Firstly, we believe "authority" is not a concept but a "relationship" (Mucchielli, 1976), which varies as a function of many elements (“situation", "group”, manager's “personality", etc.) but also in relationship with the movement of factors and parameters in time and space. If, for whatever 
reason, managers do not feel themselves legitimate and believe that they are not perceived as being legitimate by their subordinates, the fear of losing their authority and power can lead them to exercise a 'totalitarian' authority over their subordinates who could feel pain and suffering. In such cases, psychical processes are involved in the elaboration of defense mechanisms whose aim is to protect people against pathogenic surrounding conditions / events not only for the manager but also for his or her subordinates. Indeed, and often, those defense mechanisms incite the manager to give, sometimes randomly, punishment sanctions, to use violence (Arendt, 1970, 1969) or force, and / or to carry out other similar pathogenic actions which could transmit toxic effects to working people. Amongst those pathogenic effects, we will mention loss of identity and/or of esteem (Maslow, 2013), even sometimes progressive loss of "physiological" needs (Maslow, 2013).

To struggle against authoritarian management, we propose a suitable training integrating, among other things, the following goals: 1. Giving more autonomy to the workers within the limits corresponding to their knowledge, skills, competences, and abilities; 2. Allowing employees to get an overall view of the work and of its immediate environment interacting with them and their tasks; 3 . Inciting managers to set up proactive coworking not only between peers and their hierarchy but also between coworkers themselves in order to take more adequate decisions and to reduce managerial workload. At the end of such a training, the managers will become leaders-managers and will be able to manage benevolently and to build an appropriate authority relationship without applying violence (see the $7^{\text {th }}$ key point below). Amongst 'negative' pathogenic concepts put into practice by managers fearing for their authority, we will also mention some traditional beliefs regarded as 'good' management practices by untrained and / or inexperienced managers: 1. Struggle for total domination; 2. Dividing and ruling 3. "Whoever is not included is excluded" 4. "Whoever is not with me is against me" (Arendt, 1951); 5. Burying one's head in the sand, etc.

Although it is hard to list all the relevant factors for elaborating proposals concerning a suitable authority relationship including manager's legitimacy, we will synthetize as follows the main parameters involved in an authority relationship: 1. Manager's abilities, skills, and knowledge concerning the tasks carried out by the subordinates; 2. Manager's experience and expertise; 3. Degree of mutual trust between managers and subordinates; 4. Lack of pressure and coercion on the workers; 5. Manager's ethics and communication. What does distinguish a leader from a manager? In our opinion, his or her competence to be chosen, recognized or knighted as a leader by the members of a team, a group, an organization. The next example shows how a director can become legitimate even if he manages at the highest level of a large organization (See next $\S)$.

In a plant (2,000 workers, including 100 administrative people) belonging to a multinational group, breakdowns very frequently occurred. A few months after the arrival of a new director the 
breakdowns had decreased by $50 \%$. Why? At his arrival, that director talked with the workers about their tasks and as a mechanical engineer he took a real interest in technical problems which were often encountered by the handworkers. "When he looks at a non-functional equipment, he always discovers why the machine is broken", the workers said. So, he gained the trust of handworkers, the productivity increased and he was perceived as a "good" manager. Why? He perfectly knew how the machines functioned, he sometimes helped workers to solve their problems, and he was not constantly against their proposals for trying to improve safety, working conditions, and even working methods when it seemed to him that handworker' proposals were appropriate. We will add that his management principles are the opposite of these specified by Taylor (1911): "these men were deliberately breaking their machines... If any part of the machine is broken the man in charge of it must pay at least a part of the cost of its repair, and the fines collected in this way will all be handed over the mutual beneficial association to help care for sick workmen". We will add that, at his arrival in the plant, the director has understood that in most cases breakdowns were caused by the workers themselves because his predecessor 'knew nothing' about the technical tasks carried out by the workers, he didn't trust the employees and the communication was very low or inexistent, and so on.

\section{Seventh key point: the principles of ethics must not be integrated in the management of an}

organization. If, on the website of many organizations, a code of ethics is shown, the fact remains that, sometimes, some managers don't exactly know the difference between "value" and "virtue" (MacIntyre, 1981), i.e. the difference(s) between ethics and their own moral respectively ('objective' values vs. 'subjective' virtues). In fact, moral consists of principles which must be respected by people because they firmly believe that they are in accordance with their own beliefs. Nevertheless, the very large and wide set of values is not similar to the one of virtues. Managers have to respect the social and ethical values in conformity with the ethical requirements under-the-law of the organization to which they belong, in particular to win the confidence of their subordinates. Unfortunately, it is not always the case because managers often act on the strength of their own values, which are referring to moral subjective values (virtues) and not to objective ones. Furthermore, it is hard for a manager to differentiate between authority and power because both words seem to have a priori a similar meaning. Indeed, we can say that authority is not similar to power because power often induces violence whereas authority doesn't induce violence, at least a priori. In addition, "violence can destroy power" (Arendt, 1970, 1969) but it is often the case when a 'violent management' is applied.

Now, let's look at a case encountered in a home breakdown service for household appliances. That organization employed 40 technicians, 3 engineers with a broader range of skills, 2 administrative people and one engineer-manager. As a function of the type of the breakdown the repair was carried out on the spot or in the plant; a worker could never drive a vehicle assigned to her / him since anybody was 
able to work either indoors or outdoors, and thus at any time. After having discovered car registration papers and insurance documents concerning one vehicle cannot be found, the head manager asked his subordinates but nobody knew anything about that loss; since it was not possible to find the worker having lost those documents, the manager was going to punish all people when he integrated a crosscompany management training which we were managing. During this training he decided to investigate his dilemma by asking himself and his peers as follows: "Do I punish or not? Do I choose 'victims' at random in order to keep my subordinates in power? Do I punish all people? If yes, how to punish them?" After having talked about his dilemma with his peers during the training, he finally understood that an arbitrary choice could very always induce an arbitrary power and that, in that case, he had to find an alternative means of management to avoid any 're-offending". In addition, since nobody knew when and where the documents had been lost, a punishment would have been perceived as unfair and unfounded by the technicians. At the end of the training, that manager said that, without adequate management means, his first idea (i.e. to punish at random) probably came from his childhood, during which any loss had to be punished and collective punishment was often given by his teachers. That example shows the difficulty of distinguishing ethics from moral. Even if everybody can obey his own 'subjective' system of virtues, the set of 'objective' values specified by an organization must be respected by all employees, including those or these being at the highest hierarchy level (sometimes, in very big organizations some of them can or could be unknown by workmen and even sometimes by managers!); if not, many pathogenic effects could occur and the gap between occupational values and 'personal values' (virtues) can induce conflicts and occupational diseases.

\section{FOR GOING FURTHER}

Can we find management practices allowing to induce wellbeing at work? We will provide an affirmative, albeit inevitably only partial response to that question because the great number of parameters / factors to be taken in account differs from one organization to another. In our opinion, both conditions have to be met at least: 1. Management methods must be transformed from an instrument of suffering into an instrument of wellbeing at work; 2. Managers have to become leaders, and then leadersmanagers. In addition, perhaps it would make sense to introduce training models on conflict resolution in secondary school programs, for example basic concepts and rules in the field of conflict resolution (Silva, I., 2021) because managers often have to handle conflicts although they very often know neither means nor tools for resolving disputes.

Training. "Management is a practice that cannot be taught as a science or a profession; in fact, it cannot be taught at all" but "Managers can sit in small groups and consider their experience in the light of insightful concepts", Mintzberg said (2009). We agree with Mintzberg's opinion but we should 
like to end our response on an optimist note illustrating that it is quite possible to create new ways, through trainings, for improving management practices and methods, but the road will be long and sometimes painful because management is never a permanent achievement but always needs to be challenged.

Coaching. Let us look at the positive example concerning an organization where the number of employees continuously varied from 70 to 150 as a function of the ongoing contracts. The workers trained and coached people encountering difficulties to get a job (disabilities; illiteracy; lack of skills, etc.). A 55-year woman managed that association. When we received her, her request was as follows: “Can you help me to manage because I got my job, though I couldn't manage? It seems to me that I have no legitimacy because I have "worked" in that association as a volunteer but I am afraid of managing my previous coworkers. My aim is to become a 'good' manager in order to prevent employees and also me from suffering at work." This manager had worked during 10 years as a volunteer in that organization 2 days per week; when the previous director retired, the president asked her to become a director because she knew very well the running of the organization. Our coaching method was the following: 1. Firstly, past real-life cases were analyzed as a function of both psychological concepts and management principles / rules; 2. Secondly, the director tried to search for improving her behavior in several occupational situations.

Both coaching and training. We preconize a choose from case to case after having analyzed the possible factors and parameters involved in the failures in management.

Peer discussion, co-working. We emphasize that peer discussions, discussions between managers and subordinates, and co-working within a team are of great importance in the process allowing people to meet wellbeing at work.

\section{CONCLUSION}

We can compare the act of managing and the action carried out by a conductor of orchestra who directs and moves his / her baton according to methods and rules requiring expertise. If the work carried out by that conductor might, a priori, seem very easy to do, that is far from being the case. Moving a baton or giving orders is very difficult and requires knowledge, skills, and expertise. In addition, a mutual trust is necessary in a world where the numerical transition concerns more and more people facing new technologies requiring more and more 'knew' skills, abilities, etc. The "crème de la crème" would be for a manager to become a leader-manager and to be recognized as legitimate by the members of his or her team, and sometimes even to be elected by them; furthermore, this leader-manager can continuously create and develop his or her own style. However, the manager has to be aware of this main principle: authority without trust cannot go on like this because mutual trust and confidence in manager and in 
coworkers are necessary to set up lower risk for harm and to improve and finally reach wellbeing at work. 


\section{REFERENCES}

Arendt, H. (1977). Between Past and Future. What is authority? New-York: Penguin Group.

Arendt, H. (1970, 1969). On violence. New York: Harcourt.

Arendt, H. (1951). The origins of totalitarianism. New-York: Penguin Classics.

Bateson, G. (1969). Double bind in Steps to an ecology of mind. Chicago and London: The University of Chicago Press.Bourricaud, F. (1961). Esquisse d'une théorie de l'autorité. Paris: Plon.

Daujard, E. (1986). L'ergonomie: multidiscipline ou interdiscipline? in RGS. Grenoble: SAP.

Dejours, C. \& Deranty, J. P. (2015). The Centrality of work at https://www.researchgate.net/publication/275725300_The_Centrality_of_Work

Diel, P. (2007). Culpabilité et lucidité: le complexe et le mythe d'Edipe. Paris: Ed. Payot.

Freud, S., Ferenczi, S., Abraham, K., Simmel, E. \& Jones, E. (1918). Zur Psychoanalyse der Kriegsneurosen. Leipzig \& Wien: Internationaler psychoanalytischer Verlag.

Fromm, E (1967). Man for himself. An inquiry into the psychology of ethics. New York: Fawcett World Library.

Garnier-Daujard, E. (2006). Le stress collectif. Bordeaux: Ed. Préventique.

Hornby, A.S. (1974). Oxford Advanced Learner's Dictionary of Current English. Oxford: Oxford university press.

Kafka, F. (1995). Der Prozess. Husum: Hamburger Lesehefte Verlag.

Lunt, P. (2009). Stanley Milgram. Understanding obedience and its implications. New-York: Palgrave Macmillan.

MacIntyre, A. (1981). After virtue. Notre Dame: University of Notre Dame Press.

Maslow, A. (2013). A theory of human motivation. U. S. A.: Psychology Classics Series.

Milgram, S. (1974). Obedience to authority. New-York: Harper and Row.

Miller, A. (1980). Am Anfang war Erziehung. Frankfurt am Main: Suhrkamp.

Mintzberg, H. (2009). Simply managing: What managers can do and can do better. Oakland: BerrettKoehler Publishers.

Mucchielli, R. (1976). Psychologie de la relation d'autorité. Issy-les-Moulineaux: Ed. ESF.

Senfft, A. (2008). Schweigen tut weh. Berlin: Ullstein Buchverlage. 
Silva. I. \& coll (2021). Estudio de las estrategias de resolución de conflictos y habilidades sociales de alumnas y alumnos mediadores en educación secundaria obligatoria. South Florida Journal of Health, Miami: ISSN 2675-5467.

Taylor, F.M. (1911). Principles of scientific management. New-York and London: Harper \& Brothers Publishers.

Thévenet, M. (2008). Le management est-il toxique? Paris: Ed. d'organisation, Eyrolles.

Watzlawick, P., Beavin, J. H. \& Jackson, Don D. (1967). Paradoxical communication in Pragmatics of human communication. New York: Norton \& Company. 